\title{
O ESTATUTO JURÍDICO DAS PERSEGUIÇÓES DOS CRISTÃOS NO IMPÉRIO ROMANO
}

\author{
Luis Alberto De Boni ${ }^{1}$
}

RESUMO: As perseguiçôes contra os cristãos constituem um dos acontecimentos mais estudados na História do Cristianismo e na História de Roma. A esse respeito, são inúmeros os documentos existentes desde o início do segundo século de nossa era, tanto da parte dos pagãos, como da parte dos cristãos. Tomando esses documentos por base, cabe a pergunta: qual foi o estatuto jurídico no qual se basearam as autoridades romanas para perseguir os cristãos? Procuro mostrar, neste texto, que de início eram aplicadas contra eles as leis criminais vigentes. Só mais tarde se tornou crime o fato de ser cristão. Mas leis persecutórias válidas em todo o império apenas surgiram a partir do ano 250, e foram abolidas em 313.

PALAVRAS-CHAVE:: Direito romano. Perseguição aos cristãos. História do Cristianismo. Império Romano.

\section{INTRODUÇÃo}

Quando iniciei a redação deste texto sobre o estatuto jurídico das perseguiçốes de cristãos no Império Romano, pensei no número dos justiçados pelo poder público, e veio-me à mente um fato persecutório paralelo: a Inquisição, durante a qual algumas lideranças da Igreja Católica também tiraram a vida de outras pessoas, geralmente pelo crime de dissidência em questóes de fé.

Retomei então leituras antigas e, para me atualizar, procurei na Internet o que havia sobre o tema "Inquisição". Não posso deixar de dizer que me espantei. Um autor afirmou que a Igreja Católica, através da Inquisição, matou entre 70 e 100 milhóes de "hereges". Outro, mais moderado, reduziu a 40 milhóes. Outros aludiram às dezenas de milhares de bruxas queimadas (D. Brown, em $\mathrm{O}$ código de Da Vinci, declara que a Igreja queimou mais de 5 milhóes de mulheres).

\footnotetext{
${ }^{1}$ Doutorado em Münster/Alemanha, sob orientação de Johann Baptist Metz. Professor da UFRGS (1977-1992), onde foi Diretor da Faculdade de Filosofia. Professor da PUCRS (1993-2009). Atualmente, é Professor-Pesquisador da Universidade do Porto/Portugal. ladeboni@gmail.com
} 
A Inquisição não deixa de ser uma página negra na História da Igreja Católica, porém, o número de condenados à morte por ela, e que foram executados, não atingiu 10 mil pessoas ${ }^{2}$. Isso durante aproximadamente 500 anos. Ora, a Revolução Francesa, em nome de Liberté Egalité, Fraternité, nos poucos meses do Terror, guilhotinou entre 16 mil e 40 mil citoyens. De Mao-Tse Tung, Hitler, Stalin e Pol-Pot, não é necessário falar. E um olhar ao presente mostra Fidel Castro, ainda hoje herói das esquerdas e bajulado por governos, que mandou para o Paredón cerca de 17 mil pessoas, sem falar dos milhares que morreram afogados, ao tentarem fugir da ilha.

E os mártires? Quantos foram os que perderam a vida nas perseguiçôes? A tradição cristã falava em centenas de milhares, em milhôes de cristãos que o Império Romano haveria vitimado entre a perseguição de Nero (ano 64 D.C.) e a revogação das leis de Diocleciano pelo edito de Milão, em 313. Mas, como aconteceu com a Inquisição, os historiadores dos últimos séculos, dispondo de muitos dados e adotando técnicas modernas de pesquisa, após uma acurada revisão, concluem que o número de mártires foi bem menor, ficando em aproximadamente $18.000 .^{3}$

\footnotetext{
${ }^{2}$ Estudos recentes de Rino Camillieri, La Vera Storia dell' Inquisizione, Casale Monferrato, ed. PIemme 2001, p. 17 (cf.: http://www.ibs.it/code/9788838463433/cammilleri-rino/vera-storia-dell.html), mostram que houve cerca de 50 mil processos, em toda a história da Inquisição, mas apenas uma ínfima minoria acabou sendo levada à morte. Na Espanha, onde mais violenta foi a Inquisiçâao, os condenados à morte foram cerca de 800 , o que equivale a $1,8 \%$ dos indiciados. No mesmo site acima indicado, Agostino Borromeo, em uma entrevista, salienta que, na Espanha, as acusaçôes contra bruxas levaram a 49 mortes, na Itália, foram 36 e, em Portugal, 4 (Agostino Borromeo foi o organizador do volume L'inquisizione: atti del Simposio internazionale: Città del Vaticano, 29-31 ottobre 1998, Città del Vaticano, Biblioteca Apostolica. Esse Simpósio, que reuniu inúmeros historiadores, realizou-se quando da abertura dos arquivos do Santo Ofício, por ordem do papa João Paulo II. Participaram do encontro, como conferencistas ou como especialistas, estudiosos vindos da Itália, França, Espanha, Portugal, Malta, Inglaterra, Suíça, Alemanha, Dinamarca, República Tcheca, Estados Unidos e Canadá. Sobre esse tema, em língua portuguesa, cf. também AQUINO, F. Para entender a Inquisiçāo. 3. ed. Lorena: Cleofas, 2010; PERNOUD, R. A Idade Média: Que não nos ensinaram. São Paulo: Agir, 1964; ROPS, H. D. A Igreja das Catedrais e das Cruzadas. São Paulo: Quadrante, 1993, v.3.
}

${ }^{3}$ R. Gonzalez Salinero, (Le persecuzioni contro i cristiani nell'impero romano. Approccio critico, Graphe. it Edizioni, 2009) afirma que não passaram de 3 mil os mártires cristãos até o edito de 313. Já L. S. Maruotti (Sul fondamento giuridico delle persecuzioni dei cristiani, p.1.), com quem concordo, ressalta que o número de mártires deve ter sido de aproximadamente de 18.000 (disponível em: laurahttp://www.studitardoantichi.org/einfo2/file/Solidoro.pdf. Acesso em: 25 ago. 2013). Texto importante e recente sobre o Cristianismo primitivo encontra-se em PIETRI, L. (Org.). Histoire du Christianisme I, Le noveau peuple (des origines à 250). Paris: Desclée, 2000. Cf. também JOSSA, G. I Cristiani e l'impero romano da Tiberio a Marco Aurelio. Roma: Carocci, 2000. Em língua portuguesa: DREHER, M. A Igreja no Império Romano. São Leopoldo: Sinodal, 1993. 


\section{OS DADOS SOBRE OS MÁRTIRES}

O que sabemos hoje a respeito dos mártires cristáos durante o Império Romano fundamenta-se em três fontes: a) as fontes romanas, tanto textos escritos como comprovantes arqueológicos (tais como as inscrições das catacumbas); b) a descrição de martírios cristãos em escritores eclesiásticos; e c) as histórias sobre os mártires, conhecidas como "Atas dos Mártires".

As fontes romanas escritas são relativamente poucas, podendo-se citar, além de inscrições e documentos oficiais, entre outros, os textos de historiadores, como Públio Cornélio Tácito (50-120 DC) ${ }^{4}$, Caio Suetônio Tranquilo (69141), Plínio, o Moço (69-114), Dião Cássio (155-230). Documentos de cristãos dos primeiros séculos, abordando o martírio, são encontráveis em maior número, como, por exemplo, a Carta aos Coríntios do papa Clemente I (35-97), diversos textos de são Justino, Mártir (103-164), de Atenágoras (133-190), de santo Irineu (130-202), de Quinto Tertuliano (160-220), de Orígenes (185-254), de são Cipriano (200-258), de Lúcio Lactâncio (240320), de Eusébio de Cesareia ( 265-339). Por eles, temos muitas informaçóes, que precisam, porém, ser lidas com olho clínico. Também sabemos muito através dos Padres da Igreja que se seguiram, como Ambrósio (339-397), Jerônimo (347-420), João Crisóstomo (349-407), Agostinho (354-430) e Paulo Orósio (385-420).

Problemáticas se apresentam as histórias de martírio, conhecidas como Acta Martyrum (Atas dos mártires). Trata-se, na forma como as temos, de narraçôes de martírios escritas por pessoas que viveram muitas décadas ou séculos depois, as quais, em boa parte dos casos, não possuem fundamento histórico. E tais Acta se encontram em grande número ${ }^{5}$. Muitas vezes, aludem a mártires que não existiram, mas que são muito venerados até hoje, como são Jorge ou são Cristóvão; ou se referem a fatos imaginados, como o de que o profeta Elias, do Antigo Testamento, seria o fundador da Ordem dos Carmelitas; ou repetem histórias idênticas, atribuindo-as a personagens diversas.

Nessas Atas, houve até casos em que perseguidores temidos de uma região

[...] aparecem em lugares e tempos bem diferentes em outras. Assim, por exemplo, Anulinus, pro cônsul no norte da África no governo de Diocleciano, foi um modelo de perseguidor cuja atividade [para alguns autores de Atas dos Mártires] se estende até o norte da Itália, e

\footnotetext{
${ }^{4}$ As datas de nascimento e morte, aqui apresentadas, são quase todas elas aproximadas.

${ }^{5}$ Cf., a respeito: LANATA, G. Gli Atti dei Martiri come documenti processuali. Milano: Giuffré, 1973.
} 
especificamente sob os governos de Nero, Valeriano, Galieno, Maximiano e Diocleciano. ${ }^{6}$

\section{Anulinus teria então vivido cerca de 280 anos!}

O trabalho crítico de avaliação dessas fontes iniciou-se com os Bollandistas. Em 1643, o jesuíta belga João Bolland, dando prosseguimento ao que iniciara seu confrade Héribert Rosweyde, lançava os dois primeiros volumes das Acta Sanctorum 7 , que, no total, chegam hoje a 69 volumes. Para tanto, foram vasculhados arquivos em mosteiros, catedrais, bibliotecas e outras instituiçóes de toda a Europa. Valendo-se do método histórico-linguístico, eles chegaram a resultados inesperados, constatando que, das Atas de mártires que perderam a vida antes do ano de $250 \mathrm{DC}$, quando da chamada perseguição do imperador Décio, umas poucas possuem fundamento histórico. Até mesmo os relatos autênticos desse período da Igreja Primitiva foram nuançados e alterados por copistas posteriores, e são muito poucos: 1. O martírio de Policarpo; 2. Atas de Ptolomeu e Lúcio; 3. Atas de Justino e companheiros; 4. Mártires de Lyon; 5. Atas dos Mártires de Silícia; e 6. Paixão de Perpétua e Felicidade. ${ }^{8}$

Os demais relatos foram ou longamente copiados e aumentados, ou compostos longo tempo depois dos acontecimentos, por pessoas que náo haviam encontrado testemunhas oculares dos eventos descritos e menos ainda tinham elas sido testemunhas. Boa parte dos textos descartados eram romances religiosos, longos em aventuras e intrigas e curtos em probabilidade e esmero. Outros eram de um anacronismo implausível e referentes a instituiçóes, ideias e conceitos que não existiam no tempo em que viviam seus protagonistas. Outros ainda eram falsificaçôes que copiavam a forma, o estilo e por vezes até as palavras de martírios

${ }^{6}$ MOREAU, J. Die Christenverfolgung im Römischen Reich. Berlin: Töpelmann, 1961, p. 13 [as traduçóes de textos, cujo original se encontra em outra língua que não o português, são feitas pelo autor].

${ }^{7}$ Sobre o trabalho dos Bolandistas, cf. DELEHAYE, H. The Work of the Bollandistes throught Three Centuries: 1615-1915. Bruxelles: Société des Bollandistes, 1959; GODDING, R.; JOASSART, B.; LEQUEUX, X.; DE VRIENDT, F. De Rosweyde aux Acta Sanctorum. La recherche hagiographique des Bollandistes à travers quatre siècles. Bruxelles: Société des Bollandistes, 2009. Desde 1882, é publicada a revista Analecta Bollandiana, com um total de 134 números até hoje. Um resumo da história e do trabalho dos Bollandistas encontra-se na Enciclopédia Católica on-line: http:// ec.aciprensa.com/wiki/Bolandistas. (Acesso em: 24 ago. 2013). O projeto dos Bollandistas foi o de publicar a documentação referente aos santos do dia, celebrados no Martirológio, nâo se limitando, pois, apenas aos mártires dos primeiros séculos.

${ }^{8}$ MOSS, C. The Mith of Persecution: how early christians invented a story of martyrdom. New York: Harper Collings, 2013, p. 61-125. 
anteriores. Outros [...] parecem ser literalmente casas construídas sobre a areia: possuem protagonistas que nunca existiram".

Percebe-se, nos autores, a intenção de comparar o mártir a modelos cristãos, como o próprio Cristo, ou com os Macabeus e outras figuras bíblicas, mas também com sábios da cultura grega, como Sócrates. Existe mesmo uma Ata na qual o autor acabou por copiar narrativas da vida de Sidarta Gautama (conhecido como Buda) e atribuí-las ao mártir.

A tradição que surgiu dessas atas afirmava que os cristãos sofreram 10 perseguiçôes durante o Império Romano. Esse número, como se verá, não se sustenta e é mais do que provável que ele tenha sido escolhido inspirando-se nas 10 pragas do Egito, contadas pelo livro do Êxodo. Seriam fautores delas: 1 . Nero (ano 64); 2. Domiciano (ano 95); 3. Trajano (anos 108-112); 4. Marco Aurélio (ano 177); 5. Setímio Severo (ano 202); 6. Maximino Trácio (ano 236); 7. Décio (anos 249-251); 8. Valeriano (anos 257-258); 9. Aureliano (anos 270-275); 10. Diocleciano: Grande perseguição (anos 303-305), retomada por Maximiano Daia (311-313).

\section{O ESTATUTO JURÍDico DAS PERSSEGUiçÓES}

Se houve perseguiçôes, qual teria sido a lei que foi seguida para tanto? Deixamos de lado as perseguiçóes de cristáos promovidas por judeus, como se pode constatar no texto canônico dos Atos dos Apóstolos e em outros textos da tradição cristã. Também não nos adentramos na concepção de Estado do Novo Testamento, a qual orientou a atitude dos cristãos ante o poder romano. ${ }^{10}$

A tradição dizia que os milhares de mártires foram executados por ordens válidas em todo o império e emanadas do imperador. Isso, porém, tornou-se questionado nos últimos tempos. A esse respeito, surgiram três opiniōes. ${ }^{11}$

\footnotetext{
${ }^{9}$ Ibid., p. 91-92.

${ }^{10}$ Cf., a respeito: CULLMANN, O. Der Staat im Neuen Testament. 2. ed. Tübingen: J. B. Mohr, 1961.

${ }^{11}$ Cf., a propósito: VLOSOK, A. Die Rechtsgrundlagen der Christenverfolgungen der ersten zwei Jahrhunderte. In: KLEIN, R. (Ed.). Das frühe Chistentum im Römischen Reich. Darmstadt: WBG, 1971, p. 275-301. Cf. MARUOTTI, L. S. op. cit., p. 2-4; REVES, J. B. The Persecution of Christians and Ideas of Community in The Roman Empire (disponível em: http://www.academia.edu/5382548/ The_Persecution_of_Christians_and_Ideas_of_Community_in_the_Roman Empire. Acesso em: 28 ago. 2014).
} 
A primeira delas afirmava que as perseguiçóes contra os cristáos basearam-se em uma legislação especial, de alcance em todo o império. Como defensor dessa posição, que até hoje tem seguidores, encontra-se, entre outros, P. Allard ${ }^{12}$. P. Callewaert ${ }^{13}$ explicitou muito bem essa hipótese, e M. Sordi ${ }^{14}$ possui textos interessantes a respeito. Poderia ser uma lei, um senatus consultum ou um edito imperial. Tertuliano, por exemplo, cita um senatus consultum do tempo de Tibério, o qual teria servido como fundamento para as açóes de $\mathrm{Nero}^{15}$; logicamente, Domiciano teria retomado o que fora determinado por Nero, e Trajano, o que fora determinado por Domiciano. Ora, essa teoria não se mantém, pois o próprio Tertuliano menciona uma "[...] antiga e confusa floresta de leis"16; ela também não explica por que até o edito de Décio, em 250, só houve esporádicas açôes contra os cristãos e por que também os demais autores cristãos, que sustentaram a existência de uma lei persecutória, não souberam citar qual foi esta lei. "Na verdade, as disposições às quais fazem referência Tertuliano e Lactâncio parecem não serem especificamente anticristâs, mas sim normas tradicionais sobre a preservação da tradicional religião politeísta pagã, e voltadas a impedir cultos novos e estrangeiros". ${ }^{17}$

Além disso, observe-se que, em geral, os editos imperiais eram normas dirigidas para questóes específicas de uma região, ficando a aplicação ao arbítrio do governante; elas tinham caráter transitório, perdendo a validade com a morte do autor, ou mesmo antes. ${ }^{18}$ Excetuando-se a legislação sobre crimes comuns, a única lei em que se poderiam basear os funcionários imperiais para condenar os cristãos, até a perseguição de Décio, era a Lex Iulia de majestate,

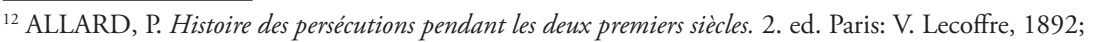
Id. Histoire des persecutions pendant la première moitié du troisième siècle. Paris: V. Lecoffre, 1881; Id. La persecution de Diocletien et le triomphe de l'Eglise. Paris: V. Lecoffre, 1890, 2v.

${ }^{13}$ CALLEWAERT, C. Les premiers chrétiens furent-ils persécutés par édits généraux ou par mesure de police?. Revue d'histoire ecclésiastique de Louvain, v. 2, p. 771-797, 1901, e v. 3, p. 5-15, 324-348, e 601-614, 1902. Id. La méthode dans la recherche de la base juridique des premières pérsecutions. Revue d'histoire ecclésiastique de Louvain, v.12, p. 5-16 e 633-651, 1911.

${ }^{14}$ SORDI, M. Il cristianesimo e Roma. Bologna: Cappelli, 1965; id. I Cristiani e l'Impero romano. Milano: Jaca Book, 1984 (2. ed. 2004).

${ }^{15}$ TERTULIANO, Ad nationes $1,7,8$.

${ }^{16}$ TERTULIANO, Apologeticum, 4, 7; apud MARUOTTI, op. cit., p. 2.

${ }^{17}$ MARUOTTI, op. cit., p. 3. A autora, no mesmo local, mostra que tal legislação de proteção ao culto romano era mencionada já por Cícero (De legibus 2. 8. 19 8), Tito Lívio (Historia 4. 3. 11) e Tácito (Annales, 3, 60-64).

${ }^{18}$ Cf. REVES, op. cit., p. 206-207; MARUOTTI, op. cit., p. 3.
} 
destinada a punir os rebeldes, e dela valeu-se Pilatos, ao condenar Jesus. Ora, a Lex Iulia não se voltava especificamente contra os cristãos.

Uma segunda opinião via a perseguição como condenação devido à recusa dos cristáos, por inertia, pertinacia ou obstinatio, a celebrar os cultos tradicionais de Roma. Isso teria ocorrido mais nas províncias que em Roma e, portanto, interessando mais aos governadores que ao imperador, de sorte que as açóes contra os cristáos, em vez de seguirem o trâmite do processo judicial, ficavam sob o poder discricionário dos governadores, a fim de, pela coerção (coercitio), manter a ordem pública. A opção religiosa podia facilmente transformar-se em política, e quem não cultuasse os deuses e o imperador se tornava apóstata da religião oficial e sujeito a ser enquadrado como traidor ou como réu de crime de lesa-majestade. Sem dúvida, nos primeiros tempos, não houve perseguição voltada diretamente contra os fiéis, mas, aos poucos, principalmente nas províncias, começou-se a considerar crime o simples fato de ser cristão. T. Mommsen, ${ }^{19}$ M. Conrat, ${ }^{20}$ E. G. Hardy ${ }^{21}$ e W. M. Ramsay ${ }^{22}$ defenderam essa posição. Outros, como E. T. Merrill ${ }^{23}$ e S. L. Guterman ${ }^{24}$, viam a condenação como crime por pertencer a uma facção ilícita ou a uma religiāo externa ou nova. Contra essa opinião, L. S. Maruotti argumenta que as Atas dos Mártires, nas quais esses autores se fundamentam, reproduzem protocolos processuais regulares. ${ }^{25}$ Além disso, prossegue a autora, ficam algumas questóes não esclarecidas, pois a teoria dá a entender que havia certa unanimidade entre os diferentes oficiais romanos, no trato com os cristãos, não se explicando igualmente o motivo pelo qual os governadores de províncias resolveram exercer a coercitio primeiramente contra os cristáos ${ }^{26}$.

\footnotetext{
${ }^{19}$ MOMMSEN, Th. Der Religionsfrevel nach römischen Recht, in: Historische Zeitschrift. München/ Leipzig: H. Oldenbourg, 1890, p. 389-429. Mommsen usou a palavra coerção (coertitio) para indicar a ação das autoridades com o fito de obrigar os cristãos a abandonar a fé.

${ }^{20}$ CONRAT, M. Die Christenverfolgungen im römischen Reiche vom Standpunkte des Juristen. Aalen: Scientia Verlag, 1973 (Nachdruck von Leipzig 1897).

${ }^{21}$ HARDY, E. G. Christianity and the Roman Government: a study in imperial administration. 3. ed. London: G. Allen \& Unwin, 1925.

${ }^{22}$ RAMSAY, W. M. The Church in the Roman Empire before A.D. 170. London : Hodder and Stoughton, 1892.

${ }^{23}$ MERRILL, E. T. Essays in early christian history. London: Macmillan and Co, 1924.

${ }^{24}$ GUTERMAN, S. L. Religious toleration and persecution in ancient Rome, London: Aiglon Press, 1951.

${ }^{25}$ MARUOTTI, op. cit., p. 3.

${ }^{26}$ REVES, op. cit., p. 206-207.
} 
Enfim, uma terceira posição considerava a perseguição como punição por parte do poder policial, em defesa da ordem pública. Os cristãos eram punidos, portanto, pelo direito penal comum, do qual os funcionários se valiam para impor a pena que julgassem cabível, e os cristãos seriam então punidos não pelo fato de serem cristãos, mas por violarem as leis romanas, como nos crimes de ateísmo, lesa-majestade, magia, superstição e os flagitia, isto é atos torpes, como incesto, infanticídio, refeiçóes onde se servia carne humana, rituais de morte etc. Quem por primeiro defendeu essa hipótese foi E. Le Blant ${ }^{27}$ e, com as devidas nuanças, ela é aceita nos últimos tempos pela maioria dos estudiosos. De fato, leis e editos imperiais contra os cristãos, bem como determinaçóes do senado, válidos em todo o império, foram poucos e só surgiram a partir do ano 250 . O que houve geralmente foram medidas tomadas por governadores, por procônsules e outros administradores locais, quando não pela turba amotinada. Nem havia então legislação classificando como sacrilégio o fato de não se prestar culto aos deuses: o culto prestado pelos cristãos a seu Deus podia ser motivo de desconfiança para os pagáos, mas, nos primeiros tempos, não era considerado crime. ${ }^{28}$

Isso posto, examinemos qual foi o fundamento jurídico que possibilitou ao Império Romano perseguir os cristãos, durante os três primeiros séculos de nossa era.

${ }^{27}$ LE BLANT, E. Sur les bases juridiques des poursuites dirigées contre les martyres. Comptes rendues de l'Academie des Inscriptions et Belles Lettres, v.10, n.1, p. 358-373, 1866.

${ }^{28}$ Uma leitura, que em muito coincide com as três teorias aqui apresentadas, é feita por Diogo da Silva, em: "As perseguiçôes aos cristãos no império romano (séc. I-IV): dois modelos de apreensão" (http:// www.revistajesushistorico.ifcs.ufrj.br/arquivos7/ARTIGO-DIOGO-DA-SILVA.pdf. Acesso em: 25 ago. 2014). Trata-se do debate surgido na década de 1960. De um lado, G.E.M. de Ste Croix (com "Why were the Early Christians persecuted? Past and Present. n. 26, p.6-38; 1963; Id. "Why were the Early Christians persecuted? - A Rejoinder", Past and Present, n. 27, p. 28-33, 1964), afirmando que o motivo principal das perseguiçóes foi a concepção romana de que os cristáos, recusando-se a adorar as divindades romanas, rompiam a pax deorum. De outro lado A. N. Sherwin-White (em "Why were the Early Christians persecuted? - An amendment", Past and Present. n. 27, p. 23-27, 1964), retomando Mommsen e outros, defendia que o motivo das perseguiçōes foi a "contumácia", isto é, a obstinação dos cristãos em não cair na apostasia e não reverenciar os deuses nem prestar culto ao imperador. Tomando uma posição diferente, Paul Veyne, em um artigo denominado Culto, piedade e moral no paganismo greco-romano (2009), argumenta que o motivo maior foi o hibridismo de que eram acusados os cristãos que, tendo a mesma cultura romana e as mesmas categorias de pensamento, eram diferentes, evitando conviver com os outros, náo participando de festas e espetáculos e não cultuando os deuses. 


\subsection{A perseguição de Nero}

No ano 54 DC, Nero, ainda jovem, tornou-se o sexto imperador romano. Haveria de reinar até o ano 68, quando, devido a seus atos criminosos, defrontou-se com uma revolta geral do senado, da guarda pretoriana e do exército, de maneira que, para não cair nas mãos dos inimigos, pediu auxílio de um guarda para suicidar-se. Seus desmandos tornaram-no detestado pelos pósteros ${ }^{29}$ : teve relaçóes sexuais com a própria mãe e, anos depois, a mandou matar; assassinou duas esposas e o filósofo Sêneca, seu preceptor; assassinou também seu meio-irmáo Britânico, que deveria ter sucedido Cláudio como imperador etc. Mas, atualmente, há os que, procurando amenizar suas maldades, realçam que ele também teve qualidades diplomáticas e administrativas; que seus anos de governo foram de prosperidade, principalmente para os pobres; que foi um homem culto, educado na Paideia grega; foi poeta, músico e apreciador da arte. ${ }^{30}$

O que, porém, mais se recorda dele, ainda hoje - e que aqui interessa -, é o incêndio de Roma, no ano $64 .{ }^{31}$ Há divergências a respeito do fato. Para alguns, Nero se encontrava em Ânzio - cerca de $60 \mathrm{~km}$ de Roma - quando surgiu o fogo; teria entáo ido a Roma e deixado que o fogo concluísse seu trabalho. Outros, como Suetônio e Diāo Cássio, garantem que o fogo foi ordenado por ele, pois desejava construir uma cidade mais linda, e funcionários imperiais teriam mesmo sido vistos pelas ruas ateando fogo. O certo é que pairavam desconfianças sobre ele como responsável pelo fogo e, a fim de safarse da situação, atribuiu a culpa aos cristãos. ${ }^{32}$ Tácito narra o fato:

Mas não através de auxílio humano, ou por doação do imperador ou com oferendas para acalmar os deuses desapareceu a desconfiança que afirmava ter sido o fogo ordenado [por ele]. Por isso, a fim de acabar com o rumor,

${ }^{29}$ Eusébio de Cesareia (cf. História Eclesiástica. Trad. de W. Fischer. São Paulo: Novo Século, 2002, p. $2,25,49)$ comenta esses fatos vergonhosos de Nero.

${ }^{30}$ Para uma crítica a essas posiçōes, cf., Giugliano, A. "Nerone santo subito", Basta Bugie (disponível em: http://www.bastabugie.it/it/articoli.php?id=1712. Acesso em: 14 ago. 2014). O elogio aos dotes de Nero, se transportado para nossos tempos, poderia ser feito em favor de Hitler, que, ao chegar ao poder, em 1933, encontrou uma Alemanha destruída e, em 1938, um ano antes de iniciar a Segunda Guerra Mundial, a transformara na segunda maior economia do mundo, superada apenas pela dos Estados Unidos. Além disso, o Führer era pintor, apreciava a música, discutia arquitetura com Albert Speer e dava muita atenção às crianças. Alguém admite que isso o absolve dos crimes cometidos?

${ }^{31}$ Cf., a respeito: BEAUJEU, J. L'incendie de Rome en 64 et les chrétiens. Latomus: révue d'études latines, n. 19, p. 65-80, 1960; GRAY-FLOW, M. J. G. Why the Christians? Nero and the great fire. Latomus, n. 57, p. 595-616, 1998.

${ }^{32}$ Cf. dentro da vasta bibliografia existente MERRILL, E. T. , op. cit., p. 80-130. 
Nero colocou a culpa e infligiu as mais terríveis torturas àqueles que por suas abominaçóes eram chamados pelo vulgo de crestianos (sic). Cristo, de quem provém este nome, fora executado no tempo do imperador Tibério pelo procurador Pôncio Pilatos. Tendo sido reprimida de início, aquela odiosa superstição ressurgiu novamente, não apenas na Judéia, local de origem do mal, mas também em Roma, para a qual confluem todas as atrocidades e vergonhas, e lá são festejadas. Por isso, primeiramente foram atacados aqueles que confessaram serem cristãos; depois, foi aprisionada uma grande multidão por acusação do povo, não tanto pelo crime do incêndio, mas pelo ódio que [os cristãos] possuem contra o gênero humano. Aos que pereciam, acrescentaram-se zombarias. Alguns, cobertos por peles de animais, foram estraçalhados por cães e pereceram; ou eram pregados a cruzes, e por vezes queimados, para servir de iluminação noturna quando a luz do dia havia expirado. Nero ofereceu seus jardins para o espetáculo, e ofereceu jogos de circo, misturando-se entre o povo em trajes de condutor de carro, ou conduzindo o carro. Por isso, embora a condenação fosse contra culpados e merecedores dos piores castigos, entre o povo surgiu pena para com eles, como se náo estivessem morrendo por utilidade pública, mas devido à crueldade de um só indivíduo ${ }^{33}$.

Tácito não conhecera Nero, a quem descreveu com cores escuras. Conviveu, porém, com Plínio, o Velho (24-79), cuja História de Nero foi perdida, no entanto, na Naturalis Historic (XVII.1), sua maior obra, existem várias referências àquele imperador, todas elas negativas. Tanto Plínio como Tácito e Diâo Cássio pertenciam à classe senatorial romana, enquanto Suetônio à classe equestre. Ora, a elite romana, por diversos motivos, odiava Nero, mas nem por isso se pode desqualificar o que esses autores escreveram sobre ele.

Pode-se questionar, em parte, o relato de Tácito. De fato, ele, escrevendo meio século depois, viu os cristáos pelos olhos de seu tempo, quando eram

\footnotetext{
33 "Sed non ope humana, non largitionibus principis aut deum placamentis decedebat infamia, quin iussum incendium crederetur. ergo abolendo rumori Nero subdidit reos et quaesitissimis poenis adfecit, quos per flagitia invisos vulgus Chrestianos appellabat. auctor nominis eius Christus Tibero imperitante per procuratorem Pontium Pilatum supplicio adfectus erat; repressaque in praesens exitiablilis superstitio rursum erumpebat, non modo per Iudaeam, originem eius mali, sed per urbem etiam, quo cuncta undique atrocia aut pudenda conflunnt celebranturque. igitur primum correpti qui fatebantur, deinde indicio eorum multitudo ingens haud proinde in crimine incendii quam odio humani generis convicti sunt. et pereuntibus addita ludibria, ut ferarum tergis contecti laniatu canum interirent aut crucibus adfixi [aut flammandi atque], ubi defecisset dies, in usu[m] nocturni luminis urerentur. hortos suos ei spectaculo Nero obtulerat, et circense ludicrum edebat, habitu aurigae permixtus plebi vel curriculo insistens. unde quamquam adversus sontes et novissima exempla meritos miseratio oriebatur, tamquam non utilitate publica, sed in saevitiam unius absumerentur" (TÁCITO, Annales, 15.44, disponível em: http://www.thelatinlibrary.com/tacitus/tac.ann15.shtml).
} 
odiados por muitos. Entretanto, é difícil supor que uma pequena comunidade, que no ano 64 começava a se estruturar e devia ser desconhecida, para a maioria da população, já tivesse provocado tanto ódio. Até mesmo o nome "cristãos" parece deslocado, pois se supóe que, no tempo de Nero, os seguidores de Cristo ainda não tivessem essa alcunha. Em compensação, Tácito, que viveu escreveu décadas antes de Suetônio e um século antes de Dião Cássio, une a perseguição dos cristãos ao incêndio de Roma - e nisto concorda com a tradição dos autores cristáos -, enquanto os outros dois autores separam os fatos.

Cabe, enfim, a pergunta: baseado em que princípio legal Nero perseguiu os cristãos? A tradição, inspirando-se nos autores cristãos do segundo e terceiro séculos, sustentava que Nero teria aplicado uma lei do ano 35, proveniente de um senatus consultum de Tibério, a qual, por isso, valia para todo o império. Tertuliano (Ad nationes I, 6,4) cita o Institutum Neronianum e, no Apologeticum (IV, 4), alude a uma fórmula que seria proveniente do senado e teria sido aplicada aos cristãos, que parece ser a do Institutum (cf. V, 3): "Non licet esse vos". Mais tarde, Sulpício Severo (363-425), em sua Crônica (II, 29), transformou a frase em "Non licet esse christianum", que passou para a posteridade. ${ }^{34}$

Ora, não se tem conhecimento de que Nero tenha apelado para tal lei, a fim de perseguir os cristãos. O que lhe estava à mão era aquela que condenava os incendiários, e dela ele se valeu - se é que não agiu apenas por arbitrariedade. Não se tratou, pois, de uma perseguição que se estendeu por todo o império, nem mesmo de uma perseguição permanente aos cristáos de Roma. ${ }^{35}$

\subsection{Domiciano}

Após a morte de Nero, sucederam-se seis imperadores (Galba, Ótão, Vitélio, Vespasiano, Tito e Domiciano), num curto espaço de 28 anos, sendo que 10 anos (69-79) foram do reinado de Vespasiano e 15 (91-96) de Domiciano.

Não há notícias sobre perseguição a cristãos, por parte de Vespasiano. Já Tito (80-81) teve como amante a judia Berenice, o que deve ter auxiliado a

\footnotetext{
${ }^{34}$ Sulpício Severo Chronica II, 29, 3, apud J. W. Ph. BORLEFFS, Institutum Neronianum, In: KLEIN, R. (Ed.) Das Frühe Christentum, p. 219. Com bons argumentos, a existência do Institutum Neronianum continua sendo defendida, como acontece com ZEILER, J. "Institutum Neronianum - Hirngespint oder Wirklichkeit”. In: KLEIN, R. (Ed.). Das Frühe Christentum, p. 236-243. Em contrário, e essa também é a nossa posição, a hipótese de inexistência de uma lei neroniana contra os cristãos é encampada por J. W. Ph. BORLEFFS, op. cit., p. 217-235.
}

${ }^{35}$ Cf. MOREAU, op. cit., p. 33-37. 
que olhasse com bons olhos os judeus de Roma e, provavelmente, também os cristãos. Textos cristãos posteriores, que consideram Vespasiano e Tito como perseguidores, não se mantêm.

Quanto a Domiciano, a tradição o considerava como sendo o fautor da segunda perseguição contra os cristãos ${ }^{36}$. Sabe-se que o imperador devotamente cultuava as divindades romanas. Muitas de suas moedas traziam a efígie de Minerva, em homenagem à qual iniciou a construção de um templo no Fórum Romano; e, no Capitólio, ele restaurou a templo de Júpiter Ótimo Máximo. Porém, não existem documentos romanos atestando que ele tenha perseguido especificamente os cristãos. Melitão de Sardes e Tertuliano ${ }^{37}$ são as fontes nas quais Eusébio de Cesareia se inspira, para se referir à perseguição encetada por Domiciano. Tanto Eusébio como Diáo Cássio contam que, no ano 95, o imperador condenou à morte seu primo Flávio Clemente, homem influente na corte, ao passo que a esposa dele, Flávia Domitila, foi exilada. Eusébio afirma que foram punidos por serem cristãos; Dião Cássio vê com outros olhos. Acontece que, em seu último ano, Domiciano assumiu uma posição contrária aos senadores e a todos os que a ele de algum modo se opunham ou podiam se opor. No caso de Flávio Clemente, não fica claro se a condenação proveio de disputas ou ambiçóes sobre a sucessão do imperador, ou em função de tendências judaizantes do casal. ${ }^{38}$

Sem dúvida, o imperador tomou medidas que atingiam também os cristãos, o que é confirmado por Diẫo Cássio ${ }^{39}$, ao relatar que Nerva (96-98), sucessor de Domiciano, mandou suspender as acusaçóes de lesa-majestade e de costumes judaicos, a fim de acabar com os abusos dos anos anteriores. ${ }^{40}$ O desprezo da religião tradicional era causa de condenação por um ato ilícito, qualificado como ateísmo, por não acreditar o condenado nos deuses tradicionais. Tertuliano ${ }^{41}$ chamou a isso de crimen laesae Romanae religionis, um crime distinto e não tão grave como o de laesae maiestatis.

\footnotetext{
${ }^{36}$ Cf. EUSÉBIO DE CESAREIA, op. cit., 3, 17, p. 61.

${ }^{37}$ TERTULIANO, Apologeticum. 4.4.

${ }^{38}$ MARUOTTI, op. cit., p. 10.

${ }^{39}$ DIÃO CÁSSIO, História romana 68. 1.2, apud MARUOTTI, L. S. op. cit. p. 10.

${ }^{40}$ Diẫo Cássio fala em "costumes judaizantes" (ibid. 67 14, 1-2, apud MARUOTTI, L. S., op. cit, p. 10), e não cita os cristãos. Depois da tomada de Jerusalém, os judeus, que viviam no império, viram sua religiáo tolerada pelo poder imperial. Já os cristãos continuaram tendo sua religião quase que ignorada pela lei.
}

${ }^{41}$ TERTULIANO, Apologeticon. 24.1. 
Há autores, porém, como A. L. Gowing ${ }^{42}$, os quais afirmam ter Domiciano suspendido medidas contra os cristãos. Parece melhor discordar das duas posiçôes, pois não existem documentos pagãos demonstrando que o imperador perseguiu e/ou editou leis de perseguição contra os cristáos, como também não se pode negar que os cristãos foram de algum modo envolvidos entre aqueles que ele condenou à morte. Como enfatiza L. S. Maruotti:

Em definitivo, quanto ao terrorismo anti-senatorial de Domiciano, é possível que a perseguiçáo desencadeada por ele por coincidência tenha envolvido os cristãos ou os simpatizantes da nova religiáo, e náo se pode de modo nenhum estar seguro que Domiciano tenha efetuado uma perseguição específica dos cristáos [...] Quanto aos primeiros imperadores, nenhum dado confiável existe a respeito de uma perseguiçáo geral especificamente anticristã. Isto não significa, de forma alguma, excluir que a nova religião não se houvesse episódica e localmente tornado objeto de manobras repressivas. ${ }^{43}$

\subsection{De Trajano a Marco Aurélio}

Após o curto reinado de Nerva (96-98), que sucedeu a Domiciano, seguiram-se, durante 82 anos, quatro longos reinados de quatro grandes imperadores: Trajano (98-117), Adriano (117-138), Antonino Pio (138/161) e Marco Aurélio (161-180). No elenco tradicional das perseguiçóes, Trajano seria o fautor da terceiraa e Marco Aurélio, da quarta perseguição.

Nos 112 anos que medeiam entre a morte de Nero e a de Marco Aurélio, o número de cristãos cresceu muito rapidamente e eles se alastraram pelo império, chamando a atenção dos pagãos. Organizados em pequenos grupos, não participavam dos festejos populares e nem do culto aos deuses;

\footnotetext{
${ }^{42}$ GOWING, A. L. Empire and memory: the representation of Roman Republic in imperial culture. Cambridge: University Press, 2005. Embora não seja um debate que desça a fundo no problema, não deixa de ser interessante comparar as posiçôes de dois pastores norte-americanos a respeito das perseguiçôes: Cf. OGDEN, A. M./JENKINS, F. Did Domitian persecute Christians? (Disponível em: http://bibleworld.com/domper.pdf Acesso em: 15 ago. 2014).

${ }^{43}$ MARUOTTI, op. cit., p. 11. Cf. MOREAU, op. cit., p. 38. A propósito, ressalta E. Truesdell Merrill (Essays in early christian history. New York: Macmillan, 1924, p. 155 e 172-173), após analisar todas as referências de pagãos e cristãos a respeito dos atos de violência de Domiciano: "But Domitian appears to have been an apostle of conformity. He did not, so far as we know, molest the Jews who were Jews by race" [...] "Domitian in his prosecution of the aristocrats was not aiming any attack against Christianity; and though Domitilla, and possibly some of the other defendants (in all probability not Clemens), may have been actually Christians, the fact did not appear in the trials, and could not have been the formal basis of the charge against them".
} 
cultuavam um único Deus, que não pertencia ao rol daqueles adorados no Panteon; reuniam-se, geralmente à noite, sem separação entre os sexos, para suas cerimônias religiosas, nas quais havia oraçôes, ensino religioso, iniciação ao batismo, celebração do culto, durante o qual recordavam a paixão de Cristo e sua ressurreição; eram presididos por um chefe coadjuvado por um grupo de anciáos, ou conselheiros; contribuíam mensalmente com certa quantia em dinheiro, que servia para auxiliar os pobres e sustentar a comunidade; houve, por vezes, comunidades que possuíam os bens em comum. Ora, aos poucos se foi desenvolvendo animosidade entre os pagãos, que viam um grupo de pessoas, pertencentes à sua cultura, seguirem costumes tão diferentes, a ponto de se afastarem dos demais. E começou-se a comentar que se tratava de um grupo que ignorava o mos maiorum (o costume dos antepassados) e se entregava às flagitia.

No governo de Trajano, Plínio, o Moço, amigo do imperador, foi nomeado governador da Bitínia, na Ásia, com poderes especiais (legatus pro praetore provinciae Pontus et Bitiniae consulari potestate). Logo, ele se deparou com um sério problema: o número de cristãos crescera muito, naquela região, e contra eles se levantavam acusações por parte dos pagãos. Plínio, não sabendo como agir corretamente, resolveu dirigir-se ao imperador. ${ }^{44}$

Ele inicia a carta (redigida em 112/113), ressalvando ter por princípio dirigir-se ao imperador nos casos duvidosos, pois ninguém melhor que o imperador o pode orientar. ${ }^{45} \mathrm{E}$ prossegue, explicitando que nunca participara de inquéritos contra os cristãos e, por isso, não sabia quais os fatos aos quais devem ser aplicadas medidas, e se cabe proceder logo à pena ou à investigação judiciária. Também náo sabia se a criança e o adulto deveriam ser julgados

${ }_{44}$ Os rescritos de Trajano, Adriano e Antonino Pio, aqui mencionados, tiveram sua autenticidade posta em dúvida em tempos passados, mas hoje são tomados como autênticos (cf. GONZALES ROMAN, C. "Problemas sociales y política religiosa a propósito de los rescriptos de Trajano, Adriano y Antonino Pio sobre los cristianos, p. 227-229”. (Disponível em: http://dialnet.unirioja. es/descarga/articulo/46023.pdf. Acesso em: 24 ago. 2014). Sobre o tema, cf. ainda SORDI, M. I rescritti di Traiano e di Adriano sui cristiani., Rivista di Storia della Chiesa in Italia, v. 14, p. 344-370, 1960. MOSS, op. cit., p. 139-145.

45 "Solemne est mihi, domine, omnia de quibus dubito ad te referre. Quis enim potest melius vel cunctationem meam regere vel ignorantiam instruere?” Por brevidade, não é apresentado aqui o texto de Plínio, nessa troca de correspondência entre ele e Trajano, com exceção de algumas palavras ou frases importantes. Para todo o texto, cf.: WILDK, Carolus Guillielmus Ignatius. D. Caecilli Secundi et imperatoris Trajani epistulis mutuis disputatio, Lugduni-Batavorum, apud J. W. Van Leeuwen, MDCCCLXXXIX [1889], p. 61-63). As obras de Plínio, o Moço, estão disponíveis em: http:// onlinebooks.library.upenn.edu/webbin/book/lookupname?key=Pliny $\% 2 \mathrm{C} \% 20$ the $\% 20$ Younger. Acesso em: 14 ago. 2014. 
da mesma forma, e se os cristãos deveriam ser punidos enquanto tais ou se apenas deveriam ser punidos os culpados que incidissem em crimes previstos em lei. A isso acrescenta a pergunta a respeito daqueles que abjuraram a fé, se deveriam ser punidos ou não.

Vê-se, pelas palavras do autor, que procedimentos processuais contra os cristãos náo eram novidade, embora Plínio jamais houvesse tomado parte neles. Nesse sentido, descrevia as atitudes que estava tomando, quando se deparava com esses casos: perguntava aos acusados se eram cristãos e, aos que diziam sêlo, repetia duas vezes a pergunta, ameaçando-os com suplícios. Se persistissem, mandava-os colocar no cárcere; se cidadãos romanos, encaminhava-os para a corte imperial. E, para tanto, argumenta que a pertinácia e a obstinação devem ser punidas, Todavia, como observa Maruotti ${ }^{46}$, ele náo especificava se a punição se deveria dar pelo direito de coerção, devido à desobediência, ou se seguida de processo por crimen maiestatis.

Plínio prossegue dizendo que, tendo recebido uma denúncia anônima com muitos nomes de cristáos, encontrou os que negavam serem cristáos, estando dispostos a fazer libação à estátua do imperador e a amaldiçoar a Cristo. A esses mandou logo libertar, porque os verdadeiros cristãos não fariam isso. Outros confessaram que haviam sido cristãos, mas não eram mais e, como prova, adoraram a estátua do imperador e dos deuses e amaldiçoaram a Cristo. Nesse ponto, narra Plínio qual a confissão desses apóstatas:

Seu erro, ou culpa, foi de se reunirem num dia fixo, antes do nascer do sol, para cantar um hino a Cristo como a um deus; de obrigarem-se, por juramento, a não cometer crimes, roubos, latrocínios e adultérios, a não faltar com a palavra dada e não negar fazer um depósito [para um fundo de auxílio aos pobres]. Findos estes ritos, tinham o costume de se reunir novamente para uma refeiçấo comum e inocente. ${ }^{47}$

Desconfiado disso, Plínio resolveu apelar para a tortura, tendo seviciado duas escravas, mas nada obteve delas. Assim sendo, não absolveu esse grupo, mas suspendeu o inquérito e resolveu consultar o imperador. $\mathrm{O}$

每MARUOTTI, op. cit., p. 11-12.

47 "Affirmabant autem hanc fuisse summam vel culpae suae vel erroris, quod essent soliti stato die ante lucem convenire carmenque Christo quasi Deo dicere secum invicem seque sacramento non in scelus aliquod obstringere, sed nec furta, nec latrocinia, nec adulteria committerent, nec fidem fallerent, nec depositum appellati abnegarent quibus peractis morem sibi discedendi fuisse rursusque cocundi ad capiendum cibum, promiscuum tamen et innoxium." 
que o preocupava era que tanto as cidades como os campos "[...] tinham sido atingidos pelo contágio dessa superstição" (superstitionis istius contagio pervagata est), isto é, uma multidão de pessoas, de todas as idades e condiçóes sociais, se fizera cristá.

O autor conclui, sua carta observando que seria possível conter esse alastramento e ele, aliás, já julgava estar havendo uma reversão, visto que os templos pagáos voltavam a ficar repletos e as carnes das oferendas voltavam a ser consumidas. Por isso, seria conveniente que se concedesse anistia aos acusados que renegassem a fé.

A curta resposta de Trajano, no preciso latim jurídico, embora não seja tão comentada como a carta de Plínio, é mais importante para o que aqui nos interessa. Escreve o imperador:

Meu caro [Plínio] Segundo, na instrutória dos processos daqueles que te foram denunciados como cristãos, seguiste o procedimento ao qual devias ater-te. Nem se pode criar uma regra universal que tenha, por assim dizer, um caráter rígido. Não devem ser procurados [os cristáos]. Mas se forem denunciados e se provar que são culpados, sejam punidos, porém de modo tal que aquele que negar ser cristáo e o demonstrar claramente, isto é, suplicando aos nossos deuses, embora suspeito no passado, receba perdáo pelo arrependimento. Quanto aos libelos anônimos, não devem merecer atenção em nenhuma causa criminal, pois são um péssimo exemplo que náo condiz com nosso tempo. ${ }^{48}$

Trajano elogiava, por conseguinte, o modo de proceder de Plínio, de quem era amigo. No entanto, logo fazia uma observação importante, ao afirmar que, nesses casos, não se podia criar uma regra única e válida em todo o império ${ }^{49}$. E, assim, o imperador traçava uma norma geral: os cristãos não devem ser perseguidos - o que está a provar que não existia antes uma lei imperial emanada contra eles. E seguia-se, como complemento, uma

48 "Actum quem debuisti, mi Secunde, in excutiendis causis eorum qui Christiani ad te delati fuerant secutus es. Neque enim in universum aliquid quod quasi certam formam habeat constitui potest. Conquirendi non sunt: si deferantur et arguantur, puniendi sunt, ita tamen ut qui negaverit se Christianum esse idque re ipsa manifestum fecerit, id est supplicando dis nostris, quamvis suspectus in praeteritum, veniam ex paenitentia impetret. Sine auctore vero propositi libelli in nullo crimine locum habere debent, nam et pessimi exempli nec nostri saeculi est." (WILDK, op. cit., p. 63).

${ }^{49}$ Em um escrito posterior dirigido a Plínio (Plin. ep. 10.113), Trajano é ainda mais claro a esse respeito: "Tenho para mim que se deve seguir a lei de cada cidade em particular, e este é sempre o método mais seguro” (apud MARUOTTI, op. cit., p. 13). 
afirmação importante e estranha: "Mas se forem acusados e se provar que são culpados, sejam punidos". Para Tertuliano, tratava-se de um absurdo: "Nega que sejam procurados porque são inocentes, e manda que sejam punidos como culpados. [...] Se condenas, porque não procuras? Se não procuras, por que não absolves?" 50

Sem negar a falta de lógica apontada por Tertuliano, cabe, porém, observar que Trajano prosseguia ordenando que fossem perdoados os que se arrependessem de ter sido cristãos, e o sinal de abjuração seria o de voltarem ao culto dos deuses romanos. Ora, por trás dessa determinação, há três importantes inovaçôes. Em primeiro lugar, Trajano não mandava que os que renegassem a fé prestassem culto à imagem do imperador. Aliás, era sabido que ele era avesso a isso e, assim sendo, a acusação contra os que não abjurassem deixava de ser enquadrada como crime de lesa-majestade, nos termos da Lex Iulia de maiestate, tornando-se apenas um crime de cunho religioso. Em segundo lugar, pelo simples fato de ser cristão, ninguém seria perseguido. Em terceiro lugar, o imperador não falava em "amaldiçoar a Cristo", algo que parecia fundamental para Plínio.

Enfim, dentro da lógica do direito romano, o qual atribuía o ônus da prova a quem acusa, o imperador desqualificava os panfletos anônimos, que não deveriam ser levados em conta pelo procônsul.

A partir dessa resposta, pode-se frisar que, ao ser ela divulgada, passou a existir uma diretiva imperial validada para uma regiáo, mas que poderia ser usada por governadores de outras províncias, a respeito do modo como os cristáos deveriam ser tratados. ${ }^{51}$ Por ela, e por outras decisóes de Trajano, fica claro que, em seu reinado, não houve perseguição imperial, mas apenas perseguiçốes locais, contra os cristãos. ${ }^{52}$ Ao que tudo indica, os cristãos (ainda) não pareciam representar uma ameaça ao império e, por isso, não havia motivo

\footnotetext{
50 "O sententiam necessitate confusam! Negat inquirendos ut innocentes, et mandat puniendos ut nocentes. Parcit et saeuit, dissimulat et animaduertit. Quid temetipsum censura circumuenis? Si damnas, cur non et inquiris? si non inquiris, cur non et absoluis? Latronibus uestigandis per uniuersas prouincias militaris statio sortitur. In reos maiestatis et publicos hostes omnis homo miles est; ad socios, ad conscios usque inquisitio extenditur. Solum Christianum inquiri non licet, offerri licet, quasi aliud esset actura inquisitio quam oblationem. Damnatis itaque oblatum quem nemo uoluit requisitum, qui, puto, iam non ideo meruit poenam, quia nocens est, sed quia non requirendus inuentus est" (TERTULIANO, Apologeticon 2.8-9).

${ }^{51}$ EUSÉBIO DE CESAREIA (op. cit., 3, 33, 2, p. 70) elogia Trajano por sua atitude, mas observa que "[...] nem por isso faltaram pretextos aos que queriam fazer-nos mal. Algumas vezes eram as populaçóes, outras as próprias autoridades locais que preparavam os assédios contra nós.”

${ }^{52}$ VLOSOK, op. cit., p. 296.
} 
para persegui-los, podendo, pelo contrário, haver uma boa convivência com eles. Contudo, igualmente se abria um precedente: o fato de ser denunciado como cristão poderia ser motivo para ser levado à justiça.

A Trajano sucedeu o estoico Adriano (117-138). Ora, era doutrina cara aos estoicos a liberdade de expressão e a igualdade entre os homens. Isso explica muitas das atitudes de Adriano, entre as quais a de ter iniciado a revisão da legislação a propósito dos escravos.

Os cristãos continuavam a crescer, principalmente na Ásia, e com isso também aumentava a aversão contra eles, por parte dos pagãos. Tendo surgido problemas, e havendo tumultos contra os cristáos, o imperador foi solicitado pelo procônsul da Ásia, Serênio Graniano, a se manifestar a respeito. A solicitação se assemelhava à carta de Plínio, o Moço, e a resposta, datada do ano 124, seguiu na linha de Trajano e foi dirigida ao sucessor de Serênio, chamado Minúcio Fundano. Declarava Adriano:

Recebi uma carta, escrita pelo preclaro senhor Serênio Graniano, ao qual tu sucedeste. E náo me parece oportuno deixar o caso sem exame para que os homens náo se sintam perturbados e para que não se dê aos delatores o aval para agirem maldosamente. Se, pois, os moradores da província são capazes de sustentar abertamente esta demanda contra os cristâos, de modo que estes possam também defender-se no tribunal, recorra-se somente a este procedimento e não às opiniôes ou clamores. De fato, é muito mais oportuno que tu instaures um processo se alguém quiser formalizar uma acusação. E então, se alguém os acusa e demonstra que eles estáo agindo contra as leis, decida segundo a gravidade do crime; mas, por Hércules, se alguém apresentar a uma denúncia caluniosa, avalia a gravidade dela e trata de puni-lo. ${ }^{53}$

A preocupação do imperador, como se pode disso deduzir, era de que houvesse paz no império e que tudo o que se fizesse fosse feito dentro da lei. Por isso, se alguém acusasse os cristãos, deveria provar o que estava dizendo, pois a ele cabia o ônus da prova. Constatando-se que era verdadeira a acusação, que o acusado fosse punido na devida forma. Caso, porém, a acusação não tivesse fundamento, fosse então punido o acusador. Além disso, pode-se compreender a resposta imperial como subentendendo que o fato de ser cristão, por não haver lei imperial em contrário, nada tinha de criminoso, o que significava que o acusador deveria mostrar que o acusado havia cometido os assim chamados

${ }^{53}$ EUSÉBIO DE CESAREIA, op. cit., 4. 8-9, 1 e 2, p. 79. 
flagitia cohaerentia nomini ou outros crimes e, nesse caso, mesmo que o cristão fosse apóstata, estaria submetido ao julgamento por crime previsto na lei. ${ }^{54}$

Antonino Pio (138-161) sucedeu a Adriano. Alguns documentos a ele atribuídos são tidos como falsos. ${ }^{55}$ As açóes contra os cristãos continuaram a aumentar, sobretudo na Ásia, de sorte estes que muitas vezes eram acusados apenas pelo crime de serem cristãos. Assim, foram condenados, em Roma, Tolomeu e Lúcio, e, em Esmirna, na Ásia, o velho bispo Policarpo, dos quais, como se viu acima, existem atas autênticas. ${ }^{56}$ Outros onze cristãos teriam sido martirizados naqueles dias, em Esmirna. Se dermos crédito a Eusébio, o imperador teria condenado a forma de execução de Policarpo, porque ela não seguiu as regras de processo do direito romano. ${ }^{57} \mathrm{O}$ que é certo a respeito da atitude de Antonino ante a religiáo cristá pode ser tomado de texto do jurista Ulpiano, o qual sintetizou um rescrito dele contra os matemáticos e os vaticinadores, pois as atividades destes podiam ser tomadas como contra quietem imperiumque populi Romani (contra a paz e o império do povo romano). ${ }^{58}$ Ora, o mesmo poderia ser visto no agir dos cristãos. ${ }^{59}$

Marco Aurélio (161-180), outro estoico, sucedeu a Antonino. Tratavase de um homem de alta cultura, verdadeiro rei-filósofo, como desejava Platão. Suas Meditaçôes ainda hoje nos encantam. ${ }^{60} \mathrm{~A}$ tradição atribui a ele a quarta perseguição.

Ao se aproximar o final do segundo século, muita coisa havia mudado no grande império. O Cristianismo crescera e atingira todas as classes. $\mathrm{Na}$ maioria das regiôes, o fato de ser cristão não era mais uma novidade ou algo de anormal.

\footnotetext{
${ }^{54}$ MARUOTTI, op. cit., p. 15 .

${ }^{55}$ Cf. VLOSK, op. cit., p. 288-289, notas 29-30.

${ }^{56}$ Eusébio de Cesareia (op. cit., 4, 14-16, p. 81-89), baseando-se em santo Irineu, conta uma longa e linda história sobre o martírio de Policarpo.

${ }^{57}$ MARUOTTI, op. cit., p. 16.

${ }^{58}$ ULPIANO coll. 15.2.3-4, apud MARUOTTI, p. 16.

${ }^{59}$ C. Gonzales Roman (“Problemas sociales y política religiosa...”, p. 231) tem uma visão diferente e toma Antonino Pio como continuador da política de Trajano e Adriano em questôes religiosas. Nesse mesmo texto (p.34-39), o autor procura explicar as causas dos levantes populares e aponta também para a crise econômica dos sacerdotes pagãos, devido à falta de fiéis.

${ }^{60}$ Cf. MARCO AURÉLIO, Meditaçôes (trad. e notas de J. Bruna), in: Epicuro, Lucrécio, Cícero, Sêneca, Marco Aurélio. São Paulo, Abril Cultural, 1973, p. 231-329 (Coleção Os Pensadores, v. 5).
} 
Nos últimos anos do reinado de Marco Aurélio e no reinado de Cômodo, os cristáos passaram, pois, a participar da vida em todos os passos do dia a dia e às claras, exceto nas cerimônias religiosas: havia entre eles senadores, nobres, altos oficiais, funcionários da corte e pessoas ricas. E eles também abriram escolas, que hoje seriam chamadas de universidades, como as de Alexandria (onde brilharam Clemente de Alexandria e Orígenes) e de Nísibis. Como não mais constituíssem um pequeno grupo formado em grande parte por pessoas simples, os cristáos passaram a chamar a atençáo de intelectuais pagãos, como Celso, Epiteto, Galeno e Porfírio. Celso publicou uma obra contra o judaísmo e, principalmente, contra o cristianismo, intitulada Alethés Lógos (Palavra verdadeira), que foi perdida e da qual somente sabemos através do livro Contra Celsum, que foi resposta de Orígenes a ele ${ }^{61}$. Porfírio escreveu o Contra christianos, do qual pouco sobrou, mas o suficiente para Agostinho mais tarde polemizar com ele.

Além disso, as coletas, criadas pelos fiéis para auxiliar os pobres e para outras finalidades da comunidade, permitiram que fossem construídos templos, nos quais se realizavam publicamente as cerimônias do culto. Esses recursos aumentaram paulatinamente e se transformaram em verdadeiros bancos financeiros - o que haveria de provocar a ganância dos governantes e a inveja e a ira de muitos, entre o povo.

Entretanto, no momento em que alguns cristãos, como Justino, depois martirizado, procuravam entabular diálogo com o mundo pagão, um movimento entre os fiéis acabou por afetar as relaçóes entre os dois grupos. Foi o Montanismo, o qual teve Tertuliano como seu maior expoente. O movimento pregava a oposição total ao mundo pagão e, em consequência, defendia a recusa ao serviço militar, aos cargos públicos, à participação nos cultos e em festejos oferecidos pelas autoridades, à adoração da pessoa e da estátua do imperador. Abandonava-se, pois, aquela relativa lealdade para com o império e se partia para o confronto e a desobediência. ${ }^{62}$

Além disso, as cerimônias determinadas por Marco Aurélio para afastar a peste que grassava, das quais os cristáos se recusaram a tomar parte, a ameaça dos bárbaros no Reno e no Oriente, a crise financeira do império e as catástrofes naturais, como a inundação de Roma pelo Tibre, serviram para aumentar a animosidade do povo, que encontrou nos cristãos o bode

${ }^{61}$ Há tradução portuguesa dessa obra: ORÍGENES. Contra Celso. Trad. de O. dos Reis. São Paulo: Paulus, 2004.

${ }^{62}$ MARUOTTI, op. cit., p. 16-17. 
expiatório. E assim veio à tona o que fervilhava no ânimo dos pagãos ${ }^{63}$. Em Lion, na Gália, por exemplo, no ano 177, explodiu um levante popular contra os cristãos. A multidão conduziu um grupo deles ante a autoridade e exigiu que fossem levados à morte, no que foram atendidos, tendo sido condenados por canibalismo e incesto. $\mathrm{O}$ mesmo acontecia nas províncias orientais, de forma que as condenações aumentavam, valendo-se a plebe de acusações como a recusa do mos maiorum, a magia, as flagitia, a ofensa aos deuses, a recusa ao culto do imperador etc. ${ }^{64}$

E como se situou Marco Aurélio neste caso? Pessoalmente, ele desprezava os cristãos. Em suas Meditaçôes, escritas em grego, destaca ele:

Que bela é a alma preparada para uma imediata separação do corpo, seja para se extinguir, seja para se dispersar ou sobreviver! Que essa preparação, porém, provenha de um juízo próprio e não de um simples sectarismo, como o dos cristáos: uma preparaçáo raciocinada, grave e, para ser conveniente, nada teatral. ${ }^{65}$

Discute-se, porém, qual sua posição no caso da perseguição. Houve editos de sua parte, os quais, porém, se perderam. Todavia, há consenso entre os historiadores cristãos de que, nesse tempo, a violência contra os cristãos se espalhou pelo império. Não se pode, contudo, atribuir a ele a perseguição. Para tanto, não foi propriamente uma lei imperial a persegui-los, mas uma delegação de poderes aos governadores de províncias para julgarem os casos com os quais se deparassem. Isso pode ter acontecido por uma praxe tolerada pelo imperador, ou induzida pela autoridade dele ou, o que foi mais comum, por serem os cristáos enquadrados em crimes previstos por lei, e não pelo fato

${ }^{63}$ Um elenco dos motivos que levava os romanos a não tolerarem os cristãos encontra-se em C. Moss (op. cit., p.170-187). A autora enumera e analisa: a Pax deorum e o culto imperial romano; a subversão; a superstição; o canibalismo e o incesto.

${ }^{64}$ Ugo Rahner (Kirche und Staat im Frühen Christentum. München: Kösel, 1961, p. 21-71), citando textos do papa Clemente, Justino, Teófilo de Antioquia, Tertuliano, Hipólito e Orígenes, mostra o esforço dos pensadores cristãos que, sem negar a autoridade do imperador, colocavam-no, porém, abaixo de Deus e, por isso, recusavam culto a ele. Um texto interessante sobre o desdobrar-se do monoteísmo no Ocidente está em PETERSON, E. Der Monoteismus als Politisches Problem. In: Theologische Traktate. München: Kösel, 1951, p. 45-146. O autor evidencia como, passado o período das perseguiçôes, alguns Padres da Igreja tomavam o Cristianismo e o Império Romano como constituindo de certo modo uma unidade. Comentando um texto de Orósio a esse respeito, E. Peterson assinala: "Assim fica claro que Augusto, deste modo, é cristianizado, e Cristo, que se torna um civis romanus, acaba romanizado" (p. 100).

${ }^{65}$ MARCO AURÉLIO, op. cit., livro 11, n. 3, p. 321-322. 
de serem cristãos. Acusados de sacrilégio, de lesa majestade, de criar sociedades proibidas, eles podiam ser condenados pela autoridade que, nem por isso, estava violando a norma de Trajano: "Christiani conquirendi non sunt" ${ }^{66}$

Pode-se, por conseguinte, concluir que, entre os governos de Trajano e de Cômodo, apesar de fatos novos que surgiram, a situação jurídica dos cristãos permaneceu sem mudanças. Eles podiam ser acusados e condenados, "[...] mas na prática gozaram de uma liberdade que não deixava de ser ameaçada, mas que, excetuando alguns períodos críticos, foi respeitada em quase todos os lugares". ${ }^{67}$

\subsection{De Cômodo a Filipe, o Árabe}

Durante quase sete décadas, entre 180 e 249, não houve medidas de perseguição contra os cristãos, excetuando-se aquela de Setímio Severo, que veremos.

Cômodo (180-92), filho de Marco Aurélio, mas sem o porte político e intelectual do pai, teve como amante uma filocristã, chamada Márcia, o que explica, em parte, seu não envolvimento em disputas religiosas.

Com os Severo, de proveniência afro-siríaca, o Cristianismo foi considerado uma das muitas religiōes do sincretismo que os inspirava. Setímio Severo (193-211) tem a seu favor o testemunho de Tertuliano, o qual, em sua carta ao procônsul Scapula ${ }^{68}$, elogiava a atitude do imperador ante os cristáos de Roma. Entretanto, em 202, em viagem à Palestina, diz-se que teria ele promulgado um edito proibindo judeus e cristãos de fazer proselitismo, e proibindo os pagãos de se converterem a essas religiôes. Difícil aceitar in totum essa afirmação, porque é conhecida sua atitude de respeito ao judaísmo. Certo é que, quando das comemoraçôes de aniversário de seu reinado, os cristãos se recusaram a prestar culto ao imperador e, com isso, reanimou-se a perseguição a eles por partes das autoridades locais, tanto na Ásia, como no Norte da África

\footnotetext{
${ }^{66}$ Cf. MARUOTTI, op cit. p. 18-20. A autora observa que os textos jurídicos de Ulpiano e Márcio, coligindo as diversas leis romanas, foram modificados e adaptados ao mundo cristâo pelos juristas de Constantinopla, ao redigirem o que chamamos de Código de Justiniano. Cf., a respeito da posição de Marco Aurélio: KERESZTES, P. Marcus Aurelius a persecutor? Harvard Divinity School. Cambridge, v. 61, n.3, p. 321-341, 1968. J. Moreau (op. cit., p. 55-59) aceita a teoria de que Marco Aurélio teria respondido à pergunta da autoridade de Lyon, afirmando que os cristăos que apostatassem deveriam ser deixados em paz; mas aqueles que se mantivessem na fé deveriam ser mortos.

${ }^{67}$ MOREAU, op. cit., p. 59.

${ }^{68}$ TERTULIANO, Ad Scapulam, 4. 6.
} 
e na Itália ${ }^{69}$. O papa Zeferino, em Roma; Perpétua e Felicidade em Cartago; Leônidas, pai de Orígenes, em Alexandria, foram alguns dos mártires. Houve também hereges, como os montanistas e os gnósticos, que perderam a vida, sem serem distinguidos dos demais cristãos pelas autoridades. Contudo, essa violência amainou em pouco tempo. Se houve, pois, algum rescrito imperial, sua aplicação teria sido de curta duração, de forma que não se conhece edito que o faça responsável pela quinta perseguição.

Mais tarde, assumiu o poder Alexandre Severo (222-235), que, como se contava (mas se coloca sob suspeita), era admirador de Jesus, de quem tinha uma estátua em seu lar, ao lado das de Abraão, Orfeu e Sócrates. Ele concedeu às igrejas cristãs o direito de se apresentar em juízo e de dispor de seus bens.

A tradição falava de Maximino Trácio (235-238) como o fautor da sexta perseguição. Sendo soldado, desprezava todos os que ficavam na retaguarda, entre eles os senadores, mas também os líderes cristãos. Bem antes de Décio e Domiciano, compreendeu que poderia destruir a Igreja sem matar fiéis em massa, bastando para tanto liquidar com seus chefes. ${ }^{70} \mathrm{O}$ que se sabe dele é que executou praticamente todos os auxiliares de Alexandre Severo, muitos dos quais eram cristãos, e que, ante a grande crise econômica do império, espoliou os templos religiosos de Roma, tanto os pagãos como os cristãos. E como houvesse exigido colaboração também dos senadores, estes conspiraram e o assassinaram. Suas ordens não foram de todo seguidas e tiveram curta duração, não se podendo afirmar que tenham constituído uma verdadeira perseguição.

Filipe, o Árabe (245-249), como o nome indica, era de proveniência oriental. Foi favorável aos cristãos, a ponto de ter sido afirmado por muitos (entre os quais são Jerônimo e Orósio) que teria recebido o batismo, tendo sido entấo o primeiro imperador cristão. Poucos aceitam isso hoje em dia, embora admitam que ele era filocristão, que entre seus auxiliares muitos eram cristãos e que não se pode atribuir a ele a revolta popular contra os cristãos, surgida em Alexandria, no final de seu reinado. ${ }^{71}$

O que se viu até aqui, quanto ao estatuto jurídico das perseguiçôes contra os cristáos dentro do Império Romano, pode ser assim resumido:

\footnotetext{
${ }^{69}$ Ibid., 3. 4, apud MARUOTTI, op. cit., p. 22.

${ }^{70}$ MOREAU, op. cit., p. 81-82.

${ }^{71}$ Ibid., p. 83.
} 
1. Não houve um edito imperial de perseguição até o ano 250. Ocorreram fatos esporádicos, descontínuos no tempo, de início em Roma e na Ásia Menor; depois, a partir da época de Marco Aurélio, pelo restante do império.

2. Muitos dos movimentos anticristáos surgiram de tumultos populares. Nesses casos, a atuação da autoridade foi inúmeras vezes passiva, até mesmo recusando as acusaçóes, ou deixando-se influenciar pelo clamor da multidão.

3. Desde o segundo século, foram emitidos vários rescritos imperiais referentes ao modo como governantes locais deveriam agir com os cristáos. Ulpiano coligiu tais rescritos, em sua obra De officio proconsulis, texto que, infelizmente, foi perdido. ${ }^{72}$

Conclui-se, pois, que as leis e editos emitidos até então não tiveram o caráter de legislação específica para perseguição dos cristãos. Tratava-se antes de indicaçôes sobre a forma como os funcionários deveriam agir, a fim de manter a paz e ordem. ${ }^{73}$ Os ataques frequentes e violentos contra os cristáos aconteceram mais nas províncias que em Roma - onde foram menos cruentos -, mas foram episódios de curta duração e sem ligação entre si. Os diferentes modos de agir das autoridades e, por vezes, “[...] o arbítrio ou o pedante legalismo"74 confirmam a não existência de uma lei geral até então.

\subsection{DÉCIO (249-251), O PERSEGUIDOR}

General de renome, Décio percebeu a decadência do império, invadido por bárbaros ao norte e pelos persas no Oriente. No meio de tantos perigos, preocupava-o a unidade do império e nada melhor do que unir as pessoas nas mesmas crenças religiosas. Por isso, o imperador incrementou o culto dos deuses pagãos e construiu templos para eles. Todavia, em Roma, as igrejas dos cristãos estavam cheias de fiéis, enquanto os templos pagãos se esvaziavam. Para mudar essa situação, já em 249, havia iniciado a perseguição dos cristãos romanos, entre os quais se encontrava o papa Fabiano, morto no início do ano seguinte.

\footnotetext{
${ }^{72}$ VLOSOK, op. cit., p. 290-291.

${ }^{73}$ Cf. VLOSOK, op. cit., p. 291.

${ }^{74}$ MOREAU, op. cit., p. 62. O quarto capítulo da obra desse autor ("Das Juristische Problem”, p. 6169) faz uma interessante análise não só da situação jurídica, mas também do modo como os cristãos viviam e eram vistos na sociedade, e como, até início do terceiro século, eram vistos pela autoridade tanto imperial como dos governadores e procônsules.
} 
Ainda no primeiro semestre de 250, lançou um edito, enviado aos governadores do império, ordenando que todos os súditos cultuassem os deuses pagãos. $\mathrm{O}$ texto desse edito foi perdido, mas inúmeras fontes pagãs e cristâs confirmam sua existência e seu conteúdo. Estabelecia o texto que, em determinada data, todas as pessoas estavam obrigadas a, na presença de autoridades nomeadas para tanto, sacrificar aos deuses romanos. Feito isso, obteriam um certificado. Mas nem era necessário oferecer sacrifício e renegar formalmente a fé; bastava jogar sobre o altar uns grãos de incenso. Houve cristãos que, por dinheiro, compraram o certificado, sem que se tivessem apresentado às autoridades; outros que, após sacrificarem aos deuses, iam pedir perdão à Igreja; em Roma, houve fiéis que simplesmente não se apresentaram e nem por isso foram perturbados. No entanto, os que se recusavam a sacrificar e eram descobertos acabavam sendo punidos. ${ }^{75}$ Muitos foram os mortos, sendo que os bispos eram especialmente procurados. Outros salvaram a vida fugindo, como fez são Cipriano, que anos depois seria martirizado. As penas, porém, nem sempre eram de morte, podendo ser a tortura, a perda de bens, alguns anos de prisão ou exílio. Houve mesmo casos em que os culpados foram liberados sem punição. Mas a perseguição não foi tão violenta como se descrevia, tendo durado pouco tempo, pois, no final daquele ano, o imperador partiu para combater os godos, os quais haviam atacado o império, e acabou tombando no campo de batalha de Abrito (atual Razgrad, na Bulgária).

A lei que regeu a perseguição de Décio foi a primeira lei válida para todo o império. Nela estava claro, mesmo que de modo indireto, que se deveria proceder à perseguição dos cristãos. Juridicamente, com esse edito, ficava superado o edito de Trajano, segundo o qual Christiani conquirendi non sunt. ${ }^{76}$

\subsection{VALERIANo (253-260)}

Ao assumir o poder, Valeriano se defrontou com a invasão dos godos no Danúbio; os francos invadiram a Gália; os persas atacavam no Oriente; as finanças estavam em frangalhos e a peste grassava pelo império.

O imperador, nos primeiros anos de reinado, mostrou-se complacente com os cristãos. Entretanto, devido ao protesto dos moradores de Cesareia

\footnotetext{
${ }^{75}$ São Cipriano, bispo de Cartago, em sua obra De lapsis (Migne, Patrologia Latina 4, col. 463-494), descreve esses fatos, dos quais foi testemunha ocular. Sobre o edito de Décio, cf. REVES, J. B. The Decree of Decius and the Religion of the Empire. Journal of Roman Studies, v. 89, p. 135-154, 1999.

${ }^{76}$ Cf. MARUOTTI, op. cit., p. 24-25.
} 
contra um senador que desrespeitara a religião local, movido pelo Senado e pela aristocracia romana, os quais pediam medidas drásticas contra os cristáos, acusados por eles de inimigos públicos e, por isso, culpados por crime de lesa majestade e, sem dúvida, forçado pela necessidade de amealhar dinheiro para financiar as guerras em que estava envolvido, Valeriano mandou que o senador fosse trazido para Roma e executado. Pouco depois, em 257, lançou um edito obrigando todos os cidadáos a tomar parte no culto dos deuses. Além disso, sob pena de morte, proibiu os cristãos de organizarem reunióes, confiscou os cemitérios e as igrejas e decretou que fossem exilados os bispos, padres e diáconos que não participassem das cerimônias oficiais. ${ }^{77}$

Já no ano seguinte um novo edito, ainda mais rigoroso, foi promulgado. Por ele, ficava claro que o simples fato de ser cristão já era crime. Eram atingidas principalmente as lideranças eclesiásticas, que, ao serem presas, deveriam ser executadas imediatamente, ficando dispensado qualquer procedimento jurídico que as condenasse; os nobres, os altos funcionários e os senadores teriam seus bens confiscados e, se insistissem em perseverar no cristianismo, deveria ser-lhes aplicada a pena de morte; as damas, além de perder os bens, seriam exiladas; e até os apóstatas eram atingidos: era-lhes poupada a vida, mas perdiam as posses.

A perseguição, a oitava para a tradição, produziu muitos mártires na África (sobretudo em Alexandria e Cartago), na Espanha, na Gália e na Ásia. Em Roma, não foi tão violenta. Felizmente, ela durou pouco tempo: no ano seguinte (260), Valeriano foi preso pelos persas, que, depois de humilhá-lo, servindo suas costas de apoio para o rei Sapor I montar a cavalo, o executaram.

Galieno, filho de Valeriano, já no início de seu governo, em 262, começou a revogar os editos do pai. Seus dois editos concediam plena liberdade aos cristãos, restituindo-lhes as igrejas, os cemitérios e demais bens, permitindo-lhes realizar seus cultos e concedendo aos bispos uma cópia de seu edito, que lhes servia como um salvo-conduto ante as autoridades. Contudo, a religião cristã não foi declarada religiâo do império, como as demais: passou a ser considerada legítima proprietária das igrejas e dos cemitérios e (na linguagem atual) foi reconhecida como pessoa jurídica, capaz de representar em juízo. ${ }^{78}$

\footnotetext{
${ }^{77}$ Cf., a respeito dessa perseguição, EUSÉBIO DE CESAREIA, op. cit. 7, 10-12, p. 154-158.

${ }^{78}$ Cf. MOREAU, op. cit., p. 92-93.
} 
Após a morte de Valeriano, os cristãos tiveram meio século de vida pacífica. Houve sempre casos de perseguição dentro do imenso império, mas constituíram exceção, como foi exceção também o período de governo de Aureliano (270-275). Soldado de carreira, ele se defrontrou com um império esfacelado. Derrotou os bárbaros em diversos fronts e, com isso, recuperou as fronteiras antigas do império. Em religião, instituiu a festa do Sol Invicto (Sol invictus) - que se encontra na origem da celebração cristã do Natal - mas não se sabe se exigiu dos súditos o culto a essa divindade, assim como náo existem provas de que tenha perseguido os cristáos, embora a tradição atribuísse a ele a nona perseguição.

\subsection{Diocleciano e Galério: a Grande Perseguição}

Em 284, Diocleciano (284-305) assumia o comando do império. Foi, sem dúvida, um dos maiores estadistas que Roma conheceu. As leis sobre a organização tributária por ele promulgadas perduraram por séculos e, quando, na década de 1970, a Comunidade Europeia fez uma reforma nessa área, comentou-se que esta estava substituindo as mais que milenares leis de Diocleciano. Devido à imensidáo do império, ele houve por bem criar uma tetrarquia para dirigi-lo: coube a ele o leste, tendo como sede Nicomédia e abrangendo a parte asiática, e Maximiano, seu melhor general, ficou no oeste, com sede em Milão, abrangendo Itália, Espanha e África, ambos com o título de Augusto, contando cada qual com um futuro sucessor, com o título de César: Galério, no Oriente, governando a Ilíria e a Grécia, e Constâncio Cloro, no Ocidente, com a Gália e a Bretanha. Essa nova forma de governo fundamentava-se em uma visão religiosa, com cerimonial copiado do Oriente, o qual tinha como de grande importância a adoratio do imperador. E Diocleciano, adotando o cognome de Júpiter, empenhado em recuperar a grandeza do império, via na unidade de religião uma condição necessária para tanto e, por isso, em suas leis, costumava apelar sempre para o mos maiorum (o costume dos antigos). ${ }^{79}$

\footnotetext{
${ }^{79}$ A respeito da perseguiçáo de Diocleciano, valho-me principalmente de J. Moreau, op. cit. p. 98-119; Cf. também, dentro de uma vasta bibliografia: MARUOTTI, op.cit., p. 26-27; KERESZTES, P. From the Great Persecution to the Peace of Galerius. Vigiliae Christianae, v. 37, n 4, p. 379-399, 1983; DAVIES, P. S. The origin and purpose of the persecution of AD 303. Journal of Theological Studies, v. 40, n. 1, p. 66-94, 1989; MAGNANI, S. Le persecuzioni in età tetrarchica. In: Studi sancanzianesi in memoria di Mario Mirabella Roberti, a cura di G. Cuscito, "AAAd", LVII. Trieste: Editreg, 2004, p. 57-76. Eusébio de Cesareia reservou todo o oitavo livro (op. cit., 8, p. 176-190) de sua obra para narrar, com cores vivas, a história dessa perseguição, da qual foi testemunha.
} 
Ele considerava os cristãos como um perigo para o império, todavia, não queria ver derramamento de sangue, de sorte que não concordava com as propostas truculentas de Galério. Por segurança, no ano 300, portanto, 16 anos após chegar ao poder, resolveu excluir os cristãos do exército e da corte, ordenando que todos os soldados e funcionários fizessem oferenda aos deuses. Os militares que recusassem deveriam ser expulsos do exército; já os funcionários, ficavam condenados ao açoite.

No dia 23 de fevereiro de 303, porém, foi emitido um edito contra os cristáos, provavelmente provocado pelos funcionários pagáos da corte e pela insistência astuciosa de Galério. ${ }^{80} \mathrm{E}$, no mesmo dia, foi incendiada a igreja cristã situada defronte ao palácio imperial, em Nicomédia. O texto do edito, do qual não se conhece o original, mas foi reportado por autores cristáos, era perfeito para seu fim e valia para todo o império. Na primeira parte, visando a impedir que os cristãos praticassem sua religião, mandava destruir as igrejas; confiscar e queimar a Sagrada Escritura, os livros litúrgicos e os documentos encontrados (isso explica por que há tão poucos documentos cristãos dos primeiros tempos); impedir qualquer tipo de reunião religiosa; confiscar os bens eclesiásticos; e, por fim, privava a Igreja do direito de entrar em juízo. Na segunda parte, voltando-se contra as pessoas, cassava os direitos civis dos cristáos; retirava o cargo e a dignidade dos funcionários e soldados que persistissem em ser cristãos e os condenava à escravidão. Não se tratava, pois, de uma perseguição contra todos os cristãos, visto que atingia apenas as lideranças religiosas e os funcionários imperiais. Entretanto, em curto tempo, por duas vezes, houve incêndio no palácio imperial, provavelmente provocado por Galério, que culpou os cristáos (o que faz recordar Nero!). Assim, por ordem de Diocleciano, os padres e diáconos foram presos e executados antes de qualquer julgamento, o bispo Anthimus foi decapitado e muitos fiéis perderam a vida.

Poucos meses depois, sendo os cristãos responsabilizados por distúrbios políticos em Melitene e na Síria, um segundo edito previa que fossem presos bispos, padres, diáconos, leitores e exorcistas. Em localidades onde os cristãos eram muito numerosos, houve cadeias que, superlotadas, obrigaram-se a libertar os criminosos. Pouco depois, um terceiro edito ordenava que fossem ouvidos os cristáos: aqueles que abjurassem a fé, deveriam ser libertados; os contumazes, duramente torturados. Um quarto edito, lançado em 304 - que,

${ }^{80}$ MAGNANI, S. (op. cit., p. 61-69), examina de quem foi a principal responsabilidade dessa perseguição e, divergindo de muitos, atribui-a a Diocleciano. 
para muitos, foi igualmente obra de Galério, porque Diocleciano se encontrava gravemente adoentado -, repetia o que fizera Décio, isto é, mandava que todos os habitantes do reino fizessem sacrifício aos deuses, devendo os que se recusassem ser imediatamente levados a juízo, cabendo como pena a morte ou o trabalho forçado nas minas.

Esses editos foram assinados pelos tetrarcas e valiam para todo o império, porém, foram aplicados de modos diferentes. Constâncio Cloro mandou destruir algumas igrejas, mas não perseguiu os fiéis. Maximiano agiu com rigor e foram muitos os mártires. Nessas regióes, em verdade, só o primeiro edito foi parcialmente aplicado. ${ }^{81} \mathrm{Na}$ região sob jurisdição de Diocleciano, a perseguiçấo foi muito violenta, podendo-se citar o caso de uma aldeia na Frígia, onde todos eram cristáos: arrastados pelos pagãos até a igreja, foram nela encerrados, e arderam nas chamas do fogo nela ateado. Galério, na região que lhe cabia administrar, e onde os cristãos não eram tão numerosos, levou muitos à morte. Mas, acima de tudo, atingiu os soldados e os membros do clero.

Essa foi, sem dúvida, a mais violenta perseguição sofrida pelos cristãos. Conta-se - mas não se sabe se é verdade -, que Diocleciano chegou a mandar cunhar uma moeda, ou erigir um monumento, onde constava a inscrição "Christiano nomine deleto" (está apagado o nome cristão).

Após a renúncia de Diocleciano e Maximiano, em 305, houve longas disputas entre diversos pretendentes aos títulos de Augusto e César ${ }^{82}$. No oeste, Constantino e Maxêncio abandonaram qualquer tipo de perseguição e adotaram atitudes favoráveis a eles, restituindo-lhes os bens e permitindo-lhes praticar a própria religiâo. Em 307, a igreja de Roma já elegia um novo papa. Já no leste, sob Galério e Maximino Daia, prosseguiu-se aplicando os editos de Diocleciano. Em 311, porém, Galério ficou gravemente doente e, temendo a morte, lançou um edito de tolerância, pelo qual permitia aos cristáos reconstruir seus templos e praticar sua religiâo, sob a condição de que orassem pela saúde do imperador. $\mathrm{O}$ cristianismo, com isso, pela primeira vez se tornava uma "religiáo lícita" no império. Pouco depois, Galério veio a falecer. Em sua parte no Oriente, Maximino Daia, ignorando o edito de Galério, continuou a perseguir os cristãos, até ser derrotado por Licínio, em 313.

\footnotetext{
${ }^{81}$ MAGNANI, op. cit., p. 61.

${ }^{82}$ Sobre as peripécias desse período, cf. MAGNANI, op. cit., p. 61-69.
} 
Com o chamado Edito de Milāo, de 313, virava-se uma página da História do Império Romano.

\section{Conclusão}

Tratar a respeito das perseguiçôes dos cristãos, durante o império romano, é algo complicado, uma vez que a pouca documentação existente nem sempre é de todo confiável. Em acréscimo, a respeito de muitos fatos não existe sequer documentação. Assim, por exemplo, sabe-se que houve perseguiçôes e motins populares contra os cristáos, em diversas províncias do império, no entanto, o que se sabe dos acontecimentos em vilarejos distantes? E mesmo em localidades maiores, quantos foram os cristáos encarcerados ou que perderam a vida?

Quanto ao estatuto jurídico, parece claro que até o ano de 250 não se teve uma lei geral de perseguição. Houve arbitrariedades, como a de Nero, além de indicaçóes imperiais destinadas a determinados governadores, a fim de que a ordem fosse mantida numa certa região. Durante muitas décadas, os cristãos foram levados a juízo sob a acusação de diversos crimes, e só bem mais tarde o fato de ser cristáo foi considerado como digno de puniçáo.

Perseguiçóes baseadas em lei imperial foram, por conseguinte, tấo somente as três últimas. Décio, Valeriano e Diocleciano, em seus editos, ordenavam que os cristãos fossem perseguidos em todo o império. Mas, mesmo no caso deles, não se pode garantir que o fim único da perseguição era a destruiçẫo dos cristãos. Como observa J. B. Reves:

Décio, Valeriano e Diocleciano participavam da mesma preocupação fundamental com a unidade e, especificamente, com a unidade religiosa do império. Apesar de suas medidas tomarem várias formas, elas todas estavam informadas por duas finalidades: de um lado, solapar ou mesmo erradicar os aspectos institucionais e comunais da Cristandade, e, por outro lado, forçar os cristãos enquanto indivíduos, e os líderes cristãos em particular, a participar das formas tradicionais de culto. ${ }^{83}$

A não participação no mesmo culto parecia-lhes ser também a não participação na comunidade do império. E isso era encarado com crime de lesa-majestade.

${ }^{83}$ REVES, op. cit., p. 215. 
DE BONI, Luis Alberto. The legal basis for the persecution of Christians in the Roman Empire. Trans/Form/Ação, Marília, v. 37, p. 135-168, 2014. Edição Especial.

\begin{abstract}
The persecutions against Christians constitute one of the most studied events in the history of Christianity and in the history of Rome. From the beginning of the second century onwards, extant documents by pagans and Christians are numerous. Based on these documents, we may ask: what was the legal basis for the Roman authorities' persecution of the Christians? I try to show in this paper that, initially, established criminal laws were applied. Only later did it become a crime to be a Christian. However, punitive laws valid in the whole Empire only emerged about the year 250, being abolished in 313 .
\end{abstract}

KEYWORDS: Roman law. Persecution of Christians. History of Christianity. Roman Empire.

\title{
Bibliografia
}

ALLARD, P. Histoire des persécutions pendant les deux premiers siècles. 2. ed. Paris: V. Lecoffre, 1892.

Histoire des persecutions pendant la première moitié du troisième siècle. Paris: V. Lecoffre, 1881.

. La persecution de Diocletien et le triomphe de l'Eglise. Paris: V. Lecoffre, 1890. 2v.

AQUINO, F. Para entender a Inquisição. 3. ed. Lorena: Cleofas, 2010.

BEAUJEU, J. L'incendie de Rome en 64 et les chrétiens. Latomus: révue d'études latines, n. 19, p. 65-80, 1960.

BORLEFFS, J. W. Ph. Institutum Neronianum. In: KLEIN, R. (Ed.). Das frühe Chistentum im Römischen Reich. Darmstadt: WBG, 1971. p. 217-235.

BORROMEO, A. (Org.) L'inquisizione: atti del simposio internazionale: Città del Vaticano, 29-31 ottobre 1998. Città del Vaticano: Biblioteca Apostolica Vaticana, 2003.

CALLEWAERT, C. Les premiers chrétiens furent-ils persécutés par édits généraux ou par mesure de police? Revue d'Histoire Ecclésiastique de Louvain, v. 2, p. 771-797, 1901, e v. 3, p. 5-15, 324-348, e 601-614, 1902.

La méthode dans la recherche de la base juridique des prèmieres pérsecutions.

Revue d'Histoire Ecclésiastique de Louvain, v. 12, p. 5-16 e 633-651, 1911.

CAMILliERI, R. La Vera Storia dell' Inquisizione. Casale Monferrato: Ed. Piemme 2001.

CIPRIANO, SÃO. De lapsis. Paris: Migne, [s.d.]. (Patrologia Latina 4, 463-494B). 
CONRAT, M. Die Christenverfolgungen im römischen Reiche vom Standpunkte des Juristen. Aalen: Scientia Verlag, 1973. (Nachdruck von Leipzig 1897).

CORNÉLIO TÁCITO, Annales, 15.44. Disponível em: < http://www.thelatinlibrary.com/ tacitus/tac.ann15.shtml >

CUllmanN, O. Der Staat im Neuen Testament. 2. ed. Tübingen: J. B. Mohr, 1961.

DAVIES, P. S. The origin and purpose of the persecution of AD 303. Journal of Theological Studies, v. 40, n. 1, p. 66-94, 1989.

DELEHAYE, H. The Work of the Bollandistes throught three centuries: 1615-1915. Bruxelles: Société des Bollandistes, 1959.

DE SMEDT, Ch.. Bolandistas (verbete). In: Enciclopedia Católica on-line. Disponível em: $<$ http://ec.aciprensa.com/wiki/Bolandistas >. p. 61-125.

DREHER, M. A Igreja no Império Romano. São Leopoldo: Sinodal, 1993.

EUSÉBIO DE CESAREIA. História eclesiástica. Trad. de W. Fischer. São Paulo: Novo Século, 2002.

GIUGLIANO, A. Nerone santo subito: Basta Bugie 189, 22/04/2011. Disponível em: $<$ http://www.bastabugie.it/it/articoli.php?id=1712 >.

GODDING, R.; JOASSART, B.; LEQUEUX, X.; DE VRIENDT, F. De Rosweyde aux Acta Sanctorum: la recherche hagiographique des Bollandistes à travers quatre siècles. Bruxelles: Société des Bollandistes, 2009.

GONZALES ROMAN, C. Problemas sociales y política religiosa a propósito de los rescriptos de Trajano, Adriano y Antonino Pio sobre los cristianos. Memorias de Historia Antigua, n. 5, p. 227-242, 1981. Disponível em: < http://dialnet.unirioja.es/descarga/ articulo/46023.pdf $>$.

GONZALEZ SALINERO, R. Le persecuzioni contro i cristiani nell'impero romano: approccio critico. [Perugia]: Graphe.it Edizioni, 2009.

GOWING, A. L. Empire and memory: the representation of Roman Republic in imperial culture. Cambridge: University Press, 2005.

GRAY-FLOW, M. J. G. Why the Christians? Nero and the great fire. Latomus, n. 57, p. 595-616, 1998.

GUTERMAN, S. L. Religious toleration and persecution in ancient Rome. London: Aiglon Press, 1951.

HARDY, E. G. Christianity and the Roman Government: a study in imperial administration. 3. ed. London: G. Allen \& Unwin, 1925.

JOSSA, G. I Cristiani e l'impero romano da Tiberio a Marco Aurelio. Roma: Carocci, 2000. 
KERESZTES, P. Marcus Aurelius a persecutor? Harvard Divinity School, Cambridge, v. 61, n.3, p. 321-341, 1968.

. From the Great Persecution to the Peace of Galerius. Vigiliae Christianae, v. 37, n 4, p. 379-399, 1983.

KLEIN, R. (Ed.). Das frühe Chistentum im Römischen Reich. Darmstadt: WBG, 1971.

LANATA, G. Gli Atti dei Martiri come documenti processuali. Milano: Giuffré, 1973.

LE BLANT, E. Sur les bases juridiques des poursuites dirigées contre les martyres. Comptes rendues de l'Academie des Inscriptions et Belles Lettres, v. 10, n.1, p. 358-373, 1866.

MAGNANI, S. Le persecuzioni in età tetrarchica. In: CUSCITO, G. (Ed.). Studi sancanzianesi in memoria di Mario Mirabella Roberti. Trieste: Editreg, 2004, p. 57-76.

MARCO AURÉLIO. Meditações. Trad. e notas de J. Bruna. In: EPICURO, Lucrécio, Cícero, Sêneca, Marco Aurélio. São Paulo: Abril Cultural, 1973. p. 231-329 (Coleção Os Pensadores, v. 5).

MARUOTTI, L. S. Sul fondamento giuridico delle persecuzioni dei cristiani. Disponível em: < http://www.studitardoantichi.org/einfo2/file/Solidoro.pdf >.

MERRILL, E. T. Essays in early christian history. London: Macmillan and Co, 1924.

MOMMSEN, Th. Der Religionsfrevel nach römischen Recht. Historische Zeitschrift, v.64, n. 3, p. 389-429, 1890.

MOSS, C. The mith of persecution: how early christians invented a story of Martyrdom. New York: Harper Collings, 2013.

MOREAU, J. Die Christenverfolgung im Römischen Reich. Berlin: Töpelmann, 1961.

OGDEN, A. M. / JENKINS, F. Did Domitian persecute Christians? Disponível em: < http://bibleworld.com/domper.pdf >. Acesso em: 15 de ago. de 2014.

ORÍGENES. Contra Celso. Trad. de O. dos Reis. São Paulo: Paulus, 2004.

PERNOUD, R. A Idade Média: que não nos ensinaram. São Paulo: Agir, 1964.

PETERSON, E. Der Monoteismus als Politisches Problem. In: Theologische Traktate. München: Kösel, 1951. p. 45-146.

RAHNER, U. Kirche und Staat im Frühen Christentum. München: Kösel, 1961.

RAMSAY, W. M. The Church in the Roman Empire before A.D. 170. London: Hodder and Stoughton, 1892.

REVES, J. B. The Decree of Decius and the religion of the Empire. Journal of Roman Studies, v. 89, p. 135-154, 1999.

The Persecution of Christians and Ideas of Community in the Roman Empire. Disponivel em: <http:/www.academia.edu/5382548/The_Persecution_of_Christians_and_Ideas_of_ Community_in_the_Roman_Empire >. Acesso em: 28 de ago. de 2014. 
ROPS, H. D. A Igreja das catedrais e das cruzadas. São Paulo: Quadrante, 1993. v. 3.

SHERWIN-WHITE, A. N. Why were the early christians persecuted? - An amendment. Past and Present, n. 27, p. 23-27, 1964.

SILVA, D. da, As perseguições aos cristãos no império romano (séc. II-IV): dois modelos de apreensão. Disponível em: < http://www.revistajesushistorico.ifcs.ufrj.br/arquivos7 >.

SORDI, M. I rescritti di Traiano e di Adriano sui cristiani. Rivista di Storia della Chiesa in Italia, v.14, p. 344-370, 1960.

. Il cristianesimo e Roma. Bologna: Cappelli, 1965.

. I Cristiani e l'Impero romano. Milano: Jaca Book, 1984.

I Cristiani e l'Impero romano. 2. ed. Milano: Jaca Book, 2004.

STE CROIX, G. E. M. de. Why were the early christians persecuted? Past and Present, n. 26, p.6-38, 1963.

. Why were the early christians persecuted? - A Rejoinder. Past and Present, n. 27, p. 28-33, 1964.

SUETÔNIO. A vida dos doze Césares. Trad. de Sady-Garibaldi. Rio de Janeiro: Tecnoprint, 1985.

TERTUliANO. Apologeticum. Paris: Migne, [s.d.]. (Patrologia Latina, v. 1, col. 257536A).

. Ad nationes. Paris: Migne, [s.d.]. (Patrologia Latina, v. 1, col. 559-608B).

. Ad Scapulam. Disponível em: < http://www.documentacatholicaomnia. eu/30_10_0160-0220__Tertullianus.html >.

TRUESDELL MERRILL, E. Essays in early christian history. New York: Macmillan, 1924.

VLOSOK, A. Die Rechtsgrundlagen der Christenverfolgungen der ersten zwei Jahrhunderte. In: KLEIN, R. (Ed.). Das frühe Chistentum im Römischen Reich. Darmstadt: WBG, 1971. p. 275-301.

WILDK, Carolus Guillielmus Ignatius. D. Caecilli Secundi et imperatoris Trajani epistulis mutuis disputatio, Lugduni-Batavorum, apud J. W.Van Leeuwen, MDCCCLXXXIX [1889], p. 61-63). As obras de Plínio, o Moço, estão disponíveis em: <http://onlinebooks. library.upenn.edu/webbin/book/lookupname?key=Pliny\%2C\%20the\%20Younger>. Acesso em: 15 de ago. de 2014.

ZEILER, J. Institutum Neronianum - Hirngespint oder Wirklichkeit”. In: KLEIN, R. (Ed.). Das frühe Chistentum im Römischen Reich. Darmstadt: WBG, 1971. p. 236-243. 